International Journal of Instruction e-ISSN: 1308-1470 • www.e-iji.net

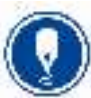

October $2020 \bullet$ Vol.13, No.4

p-ISSN: 1694-609X

pp. $731-746$

Received: 14/10/2019

Revision: 10/05/2020

Accepted: 30/05/2020

OnlineFirst:22/08/2020

\title{
Connections between Professional Well-Being and Mental Health of Early Childhood Educators
}

\section{Judit Fináncz}

Faculty of Pedagogy, Kaposvár University, Hungary, financz.judit@ke.hu

Ágnes Nyitrai

Faculty of Pedagogy, Kaposvár University, Hungary, nyitrai.agnes4@gmail.com

Judit Podráczky

Faculty of Pedagogy, Kaposvár University, Hungary, podraczky.judit@ke.hu

\section{Melinda Csima}

Faculty of Pedagogy, Kaposvár University, Hungary, melinda.csima@ gmail.com

In recent years early childhood education, along with the professionalization of staff working in this field, has been at the forefront of public interest. However, the well-being of professionals working in early childhood education has been explored only sporadically. In our cross-sectional, quantitative, descriptive research we surveyed the characteristics of professional well-being among Hungarian early childhood educators, kindergarten teachers, teaching assistants and nurses $(\mathrm{n}=1010)$, with primary emphasis on mental health. The measuring tool included questions referring to the teaching career, as well as standardized questionnaires applied in international surveys. As for workplace atmosphere, we can state that significant differences can be observed between professionals working in nurseries and kindergartens: the climate indicators of educators working is nurseries proved to be less favourable. In the sample, burnout is at low level, but three quarters of the respondents show mild depressive symptoms. The value measured on the depression scale shows a positive, close correlation with time spent in the career. Between job satisfaction, the social appreciation of workplace activity and the occurrence of depression a negative, significant correlation can be proved, which draws attention to the need for intervention.

Keywords: preschool teachers, infant \& early childhood educators, professional wellbeing, mental health, workplace atmosphere

\section{INTRODUCTION}

Preschool education has been undergoing a significant change all over the world. It is partly due to social changes such as the emancipation of women, and the growing

Citation: Fináncz, J., Nyitrai, Á., Podráczky, J., \& Csima, M. (2020). Connections between Professional Well-Being and Mental Health of Early Childhood Educators. International Journal of Instruction, 13(4), 731-746. https://doi.org/10.29333/iji.2020.13445a 
financial necessity of mothers with young children to undertake employment (the growing number of single-parent families, the effects of the economic recession). Besides, in recent years several studies have shown that time spent in institutional education before compulsory schooling, as an investment pays back multiple times and has a positive effect on the individual's career, thus, related to it, also on the reduction of social problems and inequalities (Schweinhart et al., 1993; Barnett, 2000; Heckman et al., 2010; Danis et al., 2011; OECD, 2012, 2017).

In Hungary, on 1 September 2013 the teacher career path came into effect (Act CXC of 2011, Government Decree No. 326/2013), with the following fundamental aims: to make the career attractive for the most suitable, most talented candidates, to keep good teachers in the field, to establish a predictable career path, to increase the prestige of the teaching career and to achieve differentiated salaries based on performance (Milotay, 2004; Pete, 2016). Due to changes in legislation, teachers perform more and more diverse tasks, which can significantly effect their motivation for teaching and their professional well-being. From 1 January 2016, the teacher career path was extended to early childhood educators working with a bachelor degree in nurseries.

\section{Professional Well-Being in Early Childhood Education}

The well-being of professionals working in early childhood education is a little explored field, although their well-being can determine the standards of care and education (Cumming, 2017) and it also has a great impact on rising generations' quality of life. In this respect, previous research has primarily focused on school atmosphere and the mental health of school teachers (Tímár, 2006; Cohen et al., 2009; Education Sector Health Survey, 2017), regarding teachers working with preschool children mainly local data are available (Whitaker et al., 2012; Royer \& Moreau, 2016; Saunders, 2018).

The findings of surveys concerning individual countries are controversial in many cases, which may be due to the fact that the institutional system of early childhood education, the educators' social status and qualifications differ considerably.

The exploration of the topic is made more difficult by the fact that international research literature uses a variety of terms for professionals working with preschool children: preschool teachers, early childhood teachers, educators, caregivers, interveners, family child care providers, day care teachers etc.

Underlying this, we can find the fact that in several countries early childhood education is less regulated and controlled, and thus less comparable internationally than school systems (Royer \& Moreau, 2016). Consequently, the qualification and situation of professionals working in early childhood education differ considerably among countries.

Hall-Kenyon et al. (2014) reviewed relevant literature published in the last decades on preschool teachers' well-being, focusing on the following themes: compensation, job satisfaction, stress, the role of qualification, emotional impacts, public policy and legal background, turnover and physical health. The authors concluded that all segments of preschool teachers' well-being require further research, as regarding this subject few refereed studies have been published which were based on research using large sample 
size. The authors note that preschool education is undergoing significant transformation, but at the same time little attention is paid to the well-being of preschool teachers, with focus primarily on the professionalization of education and on professional standards.

In her study, Cumming (2017) also draws attention to the complexity of professional well-being, and summarizing the most important surveys she mentions the following areas: work environment, workplace relationships, job satisfaction, psychological and emotional well-being. Royer \& Moreau (2016) examined the well-being of early childhood educators in the context of autonomy at work. During the first five years in the job position a decline in well-being can be observed, later it improves, and after the 20th year spent in early childhood education, there is a considerable improvement.

Several authors call attention to the subjective dimensions of well-being of professionals working in early childhood education, which can be an important component of the quality of early childhood education (Shpancer et al., 2008; Kusma et al., 2012; Williamson et al., 2011; Royer \& Moreau, 2016).

Considering the complexity of the topic and factors relevant in Hungary, in our study, during the examination of well-being of professionals working in early childhood education we focus on the following factors: qualification, institutional climate, mental health, sense of coherence, subjective well-being and burnout.

\section{The System of Early Childhood Education in Hungary}

In Hungary, early childhood education takes place fundamentally in two types of institutions: infants and toddlers are provided day care in nurseries between the ages of 20 weeks and 3 years; then it is compulsory for all children to go to kindergarten, starting from the pedagogical year (1st September to 31st August) following the completion of their 3rd year of age, until the age of 6 (Act CXC of 2011 on Public Education).

In nursery care, qualified early childhood educators deal with the daily care and education of young children ( 2 early childhood educators attend a group containing up to 14 children). The first three-year training course which provided a degree for the participants in early childhood education was launched in 2009 (ISCED 61). Prior to that, qualification could be obtained through various secondary and postsecondary level vocational training (ISCED 4-5).

In kindergarten education, the work of kindergarten teachers is supported by nurses and teaching assistants. The maximum number of children is 33 in each kindergarten group (the groups usually consist of 20-30 children), with two kindergarten teachers and a nurse, moreover, a teaching assistant is employed for every three groups. Since the late 1980s, kindergarten teachers have been participating in three-year graduate courses; prior to that, they could obtain qualification in various secondary and tertiary level vocational training courses. Nurses and teaching assistants obtain their qualification in shorter training courses (ISCED 3-4).

${ }^{1}$ ISCED = International Standard Classification of Education (ISCED, 2011) 
Kindergarten and nursery care is regulated by operative government and ministerial decrees (National Core Programme for Kindergarten Education, 2012; National Core Programme of Nursery Education and Care, 1998), adaptation to these is mandatory in all Hungarian institutions.

\section{METHOD}

The aim of our quantitative, cross-sectional, descriptive research is to explore the professional well-being and mental health of early childhood educators and the connection between these, seeking answers to the following questions:

- What features characterise the well-being of professionals working in early childhood education?

- What is their opinion about the institutional atmosphere in which they do their everyday activities?

- What characteristics describe the mental health of professionals working in early childhood education (subjective well-being, burnout, depression, sense of coherence)?

- How is the mental health of professionals working in early childhood education related to the perceived workplace atmosphere?

- Along what factors does the professional well-being of early childhood educators differentiate?

During the elaboration of the questionnaire the following major issues were focused on taken in consideration the studies of Aelterman et al. (2007), Cumming (2017) HallKenyon et al. (2014), Horn (2004) and Yldirim (2014): questions about job position, education, qualification, furthermore, questions about professional well-being and, in relation to it, questions concerning mental health (subjective well-being, burnout, depression, sense of coherence).

During the development of the measuring tool, in addition to standardised questionnaires used in international and Hungarian surveys (Beck Depression Questionnaire, Maslach Burnout Questionnaire, European Health Interview Survey, relevant question groups of the Psychological Immune System Inventory) we also used our own questions in order to explore the subject in greater depth.

The target group of the survey were professionals working with children in Hungarian nurseries and kindergartens (kindergarten teachers, early childhood educators, teaching assistants and nurses). Their selection was done with simple, non-random sampling. The sample included educators working in institutions which have professional connections with the Faculty of Pedagogy of Kaposvár University. In Kaposvár fullrange sampling was applied, besides, three quarters of the sample were professionals working in rural and urban kindergartens and nurseries in Budapest, furthermore, in Somogy, Zala, Baranya, Tolna, Fejér, Jász-Nagykun-Szolnok and Vas counties. After coordination with the heads of institutions respondents filled in the questionnaires in paper form, then sent them to the researchers in closed envelopes with the university 
seal. In the survey, respondents volunteered, and their anonymity was granted. The survey was completed in January 2018, the element number of the sample was 1,010 persons after recording and cleaning the data (Csima et al., 2018).

\section{Method of Statistical Analysis}

Data processing was performed used SPSS version 23.0 statistical software. For the descriptive statistical analysis absolute and relative frequency rows and average calculation were used; to explore the correlations between variables mathematical statistical probes, correlation calculations, $\chi^{2}$ probes were used; for simultaneous comparison of multiple groups one-way variance analysis (ANOVA) was used, and in the case of the absense of normality the proper non-parametric method, the KruskalWallis test was applied.

\section{FINDINGS}

\section{The Characteristics of the Sample}

As for the job position of the respondents, we can state that $41 \%$ of the sample work as early childhood educators in nurseries, $37 \%$ as kindergarten teachers, $16 \%$ as nurses and $6 \%$ is the proportion of teaching assistants. Due to the characteristics of the profession, the sample inlcudes only female respondents.

The respondents' highest level of education is closely related to their job positions: while more than $95 \%$ of those who work as kindergarten teachers have a college or university degree (ISCED 6-7), in the case of early childhood educators we get a more nuanced picture on education: the majority have post-secondary vocational qualification (ISCED 5), at the same time, in the sample employees with bachelor degree (ISCED 6), as well as ones with secondary school qualification (ISCED 4) are present. Teaching assistants mainly have secondary school qualification (ISCED 3), while nurses typically have completed vocational school training (ISCED 3) (Table 1).

Table 1

The Distribution of the Sample's Highest Level Completed Education According to Job Position ( $\mathrm{n}=992)$

\begin{tabular}{|c|c|c|c|c|c|}
\hline \multirow{2}{*}{$\begin{array}{l}\text { Education, highest level } \\
\text { completed }\end{array}$} & \multicolumn{4}{|c|}{ Job position } & \multirow[b]{2}{*}{$\begin{array}{l}\text { Total } \\
\text { sample }\end{array}$} \\
\hline & $\begin{array}{l}\text { Early } \\
\text { childhood } \\
\text { educator }\end{array}$ & $\begin{array}{l}\text { Kinder- } \\
\text { garten } \\
\text { teacher }\end{array}$ & $\begin{array}{l}\text { Teaching } \\
\text { assistant }\end{array}$ & Nurse & \\
\hline $\begin{array}{l}\text { Primary school } \\
\text { graduation }\end{array}$ & $0 \%$ & $0 \%$ & $0 \%$ & $4.4 \%$ & $0,7 \%$ \\
\hline Vocational school & $5.2 \%$ & $0 \%$ & $0 \%$ & $60.4 \%$ & $11.8 \%$ \\
\hline $\begin{array}{l}\text { Secondary school } \\
\text { graduation }\end{array}$ & $18.2 \%$ & $2.1 \%$ & $49.2 \%$ & $29.6 \%$ & $15.9 \%$ \\
\hline $\begin{array}{l}\text { Post-secondary vocational } \\
\text { training }\end{array}$ & $55.9 \%$ & $0 \%$ & $32.2 \%$ & $3.8 \%$ & $28.1 \%$ \\
\hline College/Bachelor degree & $20.0 \%$ & $95.7 \%$ & $18.6 \%$ & $1.8 \%$ & $42.4 \%$ \\
\hline University/Master degree & $0.7 \%$ & $2.2 \%$ & $0 \%$ & $0 \%$ & $1.1 \%$ \\
\hline Total & $100 \%$ & $100 \%$ & $100 \%$ & $100 \%$ & $100 \%$ \\
\hline
\end{tabular}


The problem of ageing teacher population in Hungary is strongly perceptible in the age of the sample: the average age is over 45, and several persons work in retirement. From the data (Table 2) it is clear that in the sample kindergarten teachers are the oldest $(48.42+8.93$ years of age), while the teaching assistants are the youngest $(38.12+9.29$ years of age). According to ANOVA, the age difference proved to be significant $(\mathrm{F}=$ 28.845; $\mathrm{p}<0.001)$.

Table 2

Respondents' Age and Time Spent in Their Career According to Job Position

\begin{tabular}{cllll}
\hline & Mean & Standard deviation & Min & Max \\
\hline Age, year $(\mathrm{n}=970)$ & 45.29 & 10.78 & 21 & 68 \\
\hline kindergarten teacher & 48.42 & 8.93 & 24 & 68 \\
\hline early childhood educator & 42.81 & 12.11 & 21 & 65 \\
\hline teaching assistant & 38.12 & 9.29 & 24 & 63 \\
\hline nurse & 46.92 & 8.52 & 24 & 63 \\
\hline Time spent in career, year $(\mathrm{n}=963)$ & 17.75 & 13.03 & 0.3 & 44 \\
\hline kindergarten teacher & 24.26 & 11.47 & 0.5 & 44 \\
\hline early childhood educator & 15.75 & 13.49 & 0.3 & 41 \\
\hline teaching assistant & 6.457 & 7.67 & 0.5 & 36 \\
\hline nurse & 12.15 & 9.2 & 0.5 & 35
\end{tabular}

\section{Professional Well-Being}

Firstly, we explored professional well-being and examined the main components of institutional climate. A total of eleven statements were formulated, of which the first eight are in accordance with the climate dimensions defined by Halász (1980) based on Halpin \& Croft's work (1963) and on the climate taxonomy of Tagiuri \& Litwin (1968), namely: efficiency of management, democratism of leadership, social awareness of management, coherence of teaching staff, extra-institutional relationships, activity, generational harmony, and the emotional climate of teaching staff. The items originally developed for the study of school teaching atmosphere were adapted to kindergarten and nursery environment. Furthermore, we added three extra statements to the measuring tool, and with the help of these, respondents were able to globally evaluate job satisfaction, the appreciation of colleagues and of society.

The findings show that among climate dimensions, efficiency, the coherence of teaching and professional cooperation with partner institutions can be regarded as the strengths of the institutions. However, it is a problem that respondents feel that partnership within the teaching staff is less effective. Accordingly, the professionals involved in the research feel that their colleagues do not appreciate their work properly. It has to be highlighted that their social appreciation is even lower, which can fundamentally determine the professional identity of a profession's representatives (Table 3). 
Table 3

The Climate Characteristics of Professional Well-Being

\begin{tabular}{lllll}
\hline \multicolumn{2}{l}{ Statement } & $\mathrm{N}$ & Mean & SD \\
\hline 1. & $\begin{array}{l}\text { In our institution, the teaching staff carry out teaching } \\
\text { activities along the same educational values. }\end{array}$ & 962 & 4.38 & 0.79 \\
\hline 2. & $\begin{array}{l}\text { In our institution, professionals/teachers of different } \\
\text { generations can work together in harmony. }\end{array}$ & 969 & 4.16 & 0.84 \\
\hline 3. & $\begin{array}{l}\text { The employees of our institution take part in tasks beyond } \\
\text { care and education activities in a committed and innovative } \\
\text { way. }\end{array}$ & & & \\
\hline
\end{tabular}

The value of Cronbach's Alpha, calculated on the eight statements based on the dimensions of institutional climate is 0.882 , which shows high internal consistency. Adding to it the overall satisfaction with the institution and with the appreciation of the colleagues, Cronbach's Alpha is 0.901.

\section{The Job Position - Related Features of Climate Characteristics}

During the study of climate characteristics we mapped the differences according to job position using ANOVA. Except for one statement (No.10), the differences between early childhood educators, kindergarten teachers, teaching assistants and nurses are strongly significant in all cases $(\mathrm{p}<0.05)$. Table 4 shows the differences concerning the most important dimensions from the aspect of teaching practice and professional wellbeing. 
Table 4

The Differences in Climate Characteristics of Professional Well-Being According to Job Position

\begin{tabular}{|c|c|c|c|c|c|}
\hline & \multirow[b]{2}{*}{$\mathrm{N}$} & \multirow[b]{2}{*}{ Mean } & \multirow{2}{*}{$\begin{array}{l}\text { Std. } \\
\text { Deviation }\end{array}$} & \multicolumn{2}{|c|}{ 95\% Confidence Interval } \\
\hline & & & & Lower Bound & Upper Bound \\
\hline \multicolumn{6}{|c|}{$\begin{array}{l}\text { In our institution, the teaching staff carry out teaching activities along the same educational } \\
\text { values. }(\mathrm{p}=0.014)\end{array}$} \\
\hline Early childhood educator & 386 & 4.28 & .858 & 4.19 & 4.36 \\
\hline Kindergarten teacher & 366 & 4.46 & .745 & 4.38 & 4.53 \\
\hline Teaching assistant & 57 & 4.46 & .734 & 4.26 & 4.65 \\
\hline Nurse & 144 & 4.42 & .753 & 4.29 & 4.54 \\
\hline \multicolumn{6}{|c|}{$\begin{array}{l}\text { In our institution, professionals/teachers of different generations can work together in } \\
\text { harmony. }(p=0.007)\end{array}$} \\
\hline Early childhood educator & 394 & 4.05 & .878 & 3.96 & 4.14 \\
\hline Kindergarten teacher & 363 & 4.25 & .759 & 4.18 & 4.33 \\
\hline Teaching assistant & 57 & 4.26 & .917 & 4.02 & 4.51 \\
\hline Nurse & 147 & 4.17 & .887 & 4.03 & 4.31 \\
\hline \multicolumn{6}{|c|}{$\begin{array}{l}\text { The flow of information between the head of the institution and the subordinate employees } \\
\text { functions properly. }(\mathrm{p}<0.001)\end{array}$} \\
\hline Early childhood educator & 394 & 3.82 & .993 & 3.72 & 3.92 \\
\hline Kindergarten teacher & 361 & 4.14 & .878 & 4.05 & 4.23 \\
\hline Teaching assistant & 56 & 4.21 & .967 & 3.96 & 4.47 \\
\hline Nurse & 149 & 4.11 & .909 & 3.96 & 4.25 \\
\hline \multicolumn{6}{|c|}{ I feel that my work is highly appreciated by our society. $(\mathrm{p}<0.001)$} \\
\hline Early childhood educator & 393 & 2.78 & 1.111 & 2.67 & 2.89 \\
\hline Kindergarten teacher & 363 & 3.24 & 1.072 & 3.13 & 3.35 \\
\hline Teaching assistant & 55 & 2.96 & 1.186 & 2.64 & 3.28 \\
\hline Nurse & 151 & 3.24 & 1.165 & 3.05 & 3.43 \\
\hline
\end{tabular}

Notes: Kruskal-Wallis $\mathrm{p}-$ significance level at $\mathrm{p}<0.05$

In the case of each examined dimension, we found that early childhood educators assess the climate characteristics as the most unfavourable. The reason for that may be that the professionalization of early childhood education entered in a new phase in the last one and a half decades in Hungary. The former 'caregiver' label has been replaced by the title 'early childhood educator'; at the same time, the qualifications of professionals working in nurseries vary greatly: they come from different fields of specialization (health care, social sphere, pedagogy), their educational levels are different. Consequently, their salaries differ and can cause pestige fights, professional jealousy and conflicts. All these do not favour the pedagogical activity along the same educational principles and professional values within an institution.

Besides, the lay ideas associated with the qualification are changing as well, which can be related to the potential process that, in wider public thinking, a degree in pedagogy can increase the prestige of professionals working in early childhood education.

The items concerning workplace atmosphere showed very high internal consistency according to Cronbach's Alpha values, so during the analysis, based on the statements 
referring to workplace environment, by adding up the scale values we created an aggregate indicator, with the maximum value of 50. Comparing this indicator with job position, the differences are even more marked $(\mathrm{p}<0.001)$ (Table 5).

Table 5

Aggregate Indicator of Climate Characteristics of Professional Well-Being According to Job Position

\begin{tabular}{llllll}
\hline & & & \multicolumn{2}{l}{ Std. } & \multicolumn{2}{l}{$95 \%$ Confidence Interval } \\
\cline { 5 - 6 } & $\mathrm{N}$ & Mean & Deviation & Lower Bound & Upper Bound \\
\hline Early childhood educator & 349 & 40.312 & 6.250 & 39.654 & 40.970 \\
\hline Kindergarten teacher & 341 & 42.906 & 5.914 & 42.276 & 43.536 \\
\hline Teaching assistant & 54 & 43.314 & 4.921 & 41.971 & 44.658 \\
\hline Nurse & 133 & 42.240 & 6.536 & 41.119 & 43.361 \\
\hline Total & 877 & 41.798 & 6.207 & 41.386 & 42.209
\end{tabular}

Notes: Kruskal-Wallis $\mathrm{p}-$ significance level at $\mathrm{p}<0.05$

No significant correlation was found between the years spent in work and the climate dimensions studied ( $\mathrm{p}>0.05)$.

\section{Mental Health Indicators}

We think that professional well-being - besides institution-related factors - includes certain dimensions of mental health (such as burnout), and on the other hand, it may show a correlation with them (such as depression or life satisfaction). Defining mental health, certain disciplines highlighted different aspects, so different approaches emerged.

During the exploration of early childhood educators' mental health indicators, we focused on certain dimensions of the health psychological approach (Buda, 2003), such as subjective well-being, mental balance, coping, the ability to manage stress and sense of coherence. Thus, we studied general satisfaction with life (subjective well-being), the presense of depressive symptoms, burnout and sense of coherence. According to Cronbach's Alpha values all examined variables (except for the depersonalization dimension of burnout) show high internal consistency.

\section{Life satisfaction - subjective well-being}

In our survey, in order to measure subjective well-being, we used the question containing the 11-grade scale concerning overall life satisfaction used by the European Health Interview Survey (2014/2015) during the data collection in Hungary (0 stands for 'the least satisfied' and 10 stands for 'absolutely satisfied').

Regarding the sample, it can be concluded that the index of satisfaction is the highest among kindergarten teachers $(\mathrm{p}=0.001)$ (Table 6). The background to this may be the relative homogenity of kindergarten teachers in terms of qualification and waging, furthermore, their role as teachers is socially more embedded in Hungary compared to the other examined groups. 
Table 6

Differences in Subjective Well-Being According to Job Position

\begin{tabular}{llllll} 
& & & Std. & \multicolumn{2}{l}{$95 \%$ Confidence Interval } \\
\cline { 5 - 6 } & $\mathrm{N}$ & Mean & Deviation & Lower Bound & Upper Bound \\
\hline Early childhood educator & 394 & 7.72 & 1.686 & 7.55 & 7.89 \\
\hline Kindergarten teacher & 351 & 7.91 & 1.534 & 7.75 & 8.08 \\
\hline Teaching assistant & 58 & 7.09 & 1.866 & 6.60 & 7.58 \\
\hline Nurse & 155 & 7.43 & 1.780 & 7.15 & 7.71 \\
\hline Total & 958 & 7.71 & 1.673 & 7.60 & 7.81 \\
\hline
\end{tabular}

Notes: Kruskal-Wallis $\mathrm{p}-$ significance level at $\mathrm{p}<0.05$

\section{Depressive symptoms}

In our survey, we used the abbreviated 9-item version of the Beck Depression Questionnaire to assess depressive symptoms among early childhood educators. Based on our findings, it can be stated that among the respondents severe depression occurred only in the case of one early childhood educator, however, the fact that regardless of job position, $72.6 \%$ of the sample show mild depressive symptoms, draws attention to the need of intervention and to the setting of its directions as soon as possible. The appearance of depressive symptoms shows a positive, weak significant correlation with the years spent at work $(r=0.133 ; \mathrm{p}<0.001)$. Financial appreciation associated with professional well-being may also have an impact on mental health. The starting monthly gross salary of an entrant graduate teacher is approximately 600 EUR in Hungary, which hardly exceeds $60 \%$ of the national average salary). In our questionnaire we asked the respondents to give a subjective assessment of their financial situation, which was compared with the appearance of depressive symptoms. The results demonstrate that the more uncertain the respondents feel their financial situation, the more likely the appearance of depressive symptoms is $(\chi 2=18.450 ; \mathrm{df}=8 ; \mathrm{p}=0.018)$.

\section{Burnout}

Academic literature acknowledges it as a fact that 'professions dealing with people' carry the risk that the persons exercising the profession become saturated with the problems which they face on a daily basis, so somatic, behavioural, emotional and mental symptoms appear in their lives (Fekete, 1991; Vitályos et al., 2018). Burnout, a result of the interaction between the individual and the working environment is physical and mental exhaustion as a response to chronic emotional and interpersonal stress processes (Maslach \& Jackson, 1981).

As for professionals working in early childhood education, it can be stated that burnout is not typical among them. The one-way ANOVA did not confirm any differences in any dimensions of burnout among people working in different job positions ( $p>0.05)$ (Table 7 ). Time spent at work shows a significant $(\mathrm{p}<0.05)$, but only weak correlation. All this may suggest that daily work with children and its emotional charge functions as a protective factor against burnout. 
Table 7

The Main Characteristics of Burnout

\begin{tabular}{|c|c|c|c|c|c|}
\hline & \multirow[t]{2}{*}{$\mathrm{N}$} & \multirow[t]{2}{*}{ Mean } & \multirow[t]{2}{*}{ SD } & \multicolumn{2}{|c|}{$95 \%$ Confidence Interval } \\
\hline & & & & Lower Bound & Upper Bound \\
\hline depersonalization & 914 & 6.64 & 2.67 & 6.47 & 6.82 \\
\hline emotional exhaustion & 868 & 23.96 & 9.31 & 23.34 & 24.58 \\
\hline reduced personal accomplishment & 872 & 48.32 & 5.97 & 47.93 & 48.72 \\
\hline
\end{tabular}

Notes: ANOVA p - significance level at $\mathrm{p}<0.05$

\section{Sense of coherence}

In Antonovsky's interpretation (1996) coherence is in fact the experience that the individual has a place in the world, which means an interaction between the individual and his environment. It also means that the individual controls his life and is not exposed to the impacts that affect him because he is able to shape them. Moreover, sense of coherence also shows a correlation with subjective well-being, a central element of quality of life, and this correlation is also confirmed by the results of the Hungarostudy 2002 survey (Kopp \& Kovács, 2006).

Sense of coherence was measured on the basis of the relevant subscale of the Psychological Immune System Inventory, according to which the Hungarian average is 15.97 (Kopp \& Kovács, 2006) and the same value is 17.63 among professionals working in early childhood education $(\mathrm{SD}=2.55)$. Both job position and the highest level of education proved to be differentiating factors $(p<0.001)$ : the strongest sense of coherence can be proved among those with the highest level of education, mainly among kindergarten teachers (Tables 8-9).

Table 8

Differences in Sense of Coherence According to Job Position

\begin{tabular}{llllll}
\hline Job position & N & Mean & SD & \multicolumn{2}{l}{$95 \%$ Confidence Interval } \\
\cline { 5 - 6 } & & & & Lower Bound & Upper Bound \\
\hline Early childhood educator & 369 & 17.71 & 2.51 & 17.45 & 17.97 \\
\hline Kindergarten teacher & 328 & 18.04 & 2.33 & 17.79 & 18.30 \\
\hline Teaching assistant & 56 & 17.14 & 2.60 & 16.44 & 17.84 \\
\hline Nurse & 134 & 16.56 & 2.81 & 16.08 & 17.79 \\
\hline Total & 887 & 17.63 & 2.55 & 17.46 & \\
\hline
\end{tabular}

Notes: Kruskal-Wallis $\mathrm{p}-$ significance level at $\mathrm{p}<0.05$

Table 9

Differences in Sense of Coherence According to Highest Level of Completed Education

\begin{tabular}{|c|c|c|c|c|c|}
\hline \multirow[t]{2}{*}{ Education, highest level completed } & \multirow[t]{2}{*}{$\mathrm{N}$} & \multirow[t]{2}{*}{ Mean } & \multirow[t]{2}{*}{ SD } & \multicolumn{2}{|c|}{$95 \%$ Confidence Interval } \\
\hline & & & & Lower Bound & Upper Bound \\
\hline primary school & 5 & 16.4 & 3.50 & 12.04 & 20.75 \\
\hline vocational school & 97 & 16.37 & 2.99 & 15.76 & 16.97 \\
\hline comprehensive school, grammar school & 141 & 17.34 & 2.53 & 16.92 & 17.76 \\
\hline post-secondary vocational training & 252 & 17.71 & 2.45 & 17.40 & 18.01 \\
\hline college/bachelor degree & 384 & 17.96 & 2.39 & 17.72 & 18.20 \\
\hline university/master degree & 12 & 19.16 & 1.19 & 18.40 & 19.92 \\
\hline Total & 891 & 17.63 & 2.54 & 17.46 & 17.79 \\
\hline
\end{tabular}

Notes: Kruskal-Wallis $\mathrm{p}-$ significance level at $\mathrm{p}<0.05$ 
According to the well-being and quality of life questionnaire of the WHO, high sense of coherence is associated with better quality of life (Skrabski et al., 2006), which was also proved by our study. Among professionals working in early childhood education, a moderate, positive, significant correlation can be found between sense of coherence and subjective well-being $(r=0.457 ; \mathrm{p}<0.001)$.

\section{DISCUSSION}

Educators' professional wellbeing is essential for the quality of early childhood education (Cumming, 2017; Hall-Kenyon et al. 2014). As for institutional climate dimensions determining professional well-being, based on our research, it can be said that efficiency, coherent educational principles and good professional cooperation with partner institutions can be regarded as strengths, but respondents feel that the social appreciation of their profession is rather low.

We compared the aggregate institutional climate indicator created by adding up the scale values of the workplace environment, as well as the social appreciation of workplace activity and job satisfaction with various indicators of mental health such as burnout, depression and subjective well-being (Table 10).

Table 10

The Correlations of Institutional Climate and Mental Health

\begin{tabular}{llllll}
\hline & Depersonalization & $\begin{array}{l}\text { Emotional } \\
\text { exhaustion }\end{array}$ & $\begin{array}{l}\text { Reduced personal } \\
\text { accomplishment }\end{array}$ & Depression & $\begin{array}{l}\text { Subjective } \\
\text { well-being }\end{array}$ \\
\hline $\begin{array}{l}\text { Institutional } \\
\text { climate } \\
\text { indicator }\end{array}$ & $\mathrm{r}=-0.235^{*}$ & $\mathrm{r}=-0.225^{*}$ & $\mathrm{r}=0.295^{*}$ & $\mathrm{r}=-0.249^{*}$ & $\mathrm{r}=0.194^{*}$ \\
\hline $\begin{array}{l}\text { Social } \\
\text { appreciation }\end{array}$ & $\mathrm{r}=-0.049$ & $\mathrm{r}=-0.190^{*}$ & $\mathrm{r}=0.180^{*}$ & $\mathrm{r}=-0.180^{*}$ & $\mathrm{r}=0.243^{*}$ \\
\hline $\begin{array}{l}\text { Job } \\
\text { satisfaction }\end{array}$ & $\mathrm{r}=-0.222^{*}$ & $\mathrm{r}=-0.302^{*}$ & $\mathrm{r}=0.275^{*}$ & $\mathrm{r}=-0.290^{*}$ & $\mathrm{r}=0.256^{*}$ \\
\hline
\end{tabular}

Notes: $\mathrm{r}-$ Pearson's correlation coefficient; ${ }^{*}-\mathrm{p}-$ significance level at $\mathrm{p}<0.01$

Our findings prove that, with only one exception (social appreciation vs depersonalization), in all cases there is a weak, significant correlation among the examined variables. Depersonalization, emotional exhaustion and depression correlate negatively with institutional climate indicators, so the more unfavourable the environment is in which educators do their work, the more unfavourable their mental health indicators are. Personal accomplishment and subjective well-being have a positive correlation with mental health, which means that a more favourable assessment of the working environment has a positive effect on subjective well-being and on the values measured on the subscale of personal accomplishment concerning burnout. It would be interesting to examine our results in an international context, but due to differences in the early childhood education systems in each country, currently, no relevant data are available.

\section{CONCLUSIONS}

This study was initiated to explore the relationship between professional well-being and mental health of early childhood educators in Hungary. In terms of the examined climate 
dimensions, it has been found that early childhood educators working in nurseries assess the climate characteristics of their workplace as the most unfavourable, which may be due to their heterogeneus composition and the professionalization of their education, which is still in progress in Hungary.

Regarding mental health, it can be stated that though mild depression affects a considerable proportion of respondents, burnout is not typical among them. Mild depressive symptoms are definitely present in Hungarian society, especially in those social groups where constant chronic stress and insecurity are parts of everyday life (Kopp \& Skrabski, 2006). In the case of the respondents, depressive symptoms have a correlation with their unfavourable financial situation and the resulting existential insecurity. The low level of burnout found in the sample may be due to the characteristics of the career: dealing with young children appears as a protective factor.

Certainly this does not mean that burnout does not endanger early childhood educators, as, on the one hand, emotional exhaustion shows an increasing trend in relation with the length of time spent in the career. On the other hand, this study focused on the emotional, mental and behavioural symptoms of burnout, and somatic factors were not dealt with.

Low salaries and ongoing professionalization impact the social appreciation of teachers working in early childhood education unfavourable which may long-term decrease the attractiveness of the career path and endanger the professional recruitment. Based on the explored correlations, depression and burnout are closely related to workplace atmosphere, which draws attention to the need to improve educators' well-being starting from an institutional level.

\section{LIMITATIONS}

The instrument for this study was a self-reported questionnaire that may have influenced the answers to questions about the institutional climate. The respondents of our research were selected by simple, non-random sampling, therefore it may not be representative for the whole population of professionals working in early childhood education in Hungary. Despite this limitation the results of our study are promising.

\section{CONFLICT OF INTERESTS}

The authors declare no conflict of interests regarding this article.

\section{REFERENCES}

326/2013. (VIII.30.) 326/2013. (VIII.30.) Kormányrendelet a pedagógusok elömeneteli rendszeréröl és a közalkalmazottak jogállásáról szóló 1992. évi XXXIII. törvény köznevelési intézményekben történő végrehajtásáról [Government Decree on the execution of the 1992/XXXIII Act on teachers' promotional system and on the status of public servants in public educational institutions].

363/2012. (XII. 17.) 363/2012. (XII. 17.) Korm. rendelet az Óvodai nevelés országos alapprogramjáról [Government Decree on the National Core Programme for Kindergarten Education]. 
2011. évi CXC. törvény a nemzeti köznevelésröl [Act CXC of 2011 on Public Education - Hungary].

10. melléklet a 15/1998 (IV. 30.) NM Rendelethez: A bölcsödei nevelés-gondozás országos alapprogramja [Annex to 15/1998 (4. 30.) NM Decree: National Core Programme For Nursery Care and Education - Hungary].

Aelterman, A., Engels, N., Petegem, K. V., \& Verhaeghe, J.P. (2007). The wellbeing of teachers in Flanders: The importance of a supportive school culture. Educational Studies, 33(3), 285-297. https://doi.org/10.1080/03055690701423085.

Antonovsky, A. (1996). The salutogenic model as a theory to guide health promotion. Health Promotion International, 11(1), 11-18.

Barnett, W. S. (2000). Economics of early childhood education. In J. P. Shonkoff, \& S. J. Meisels, (Eds.), Early Childhood Intervention (pp. 589-612). Cambridge, Cambridge University Press.

Buda, B. (2003). A lélek egészsége. A mentálhigiéné alapkérdései - A mentálhigiéné alapkérdései [The Health of the Soul. The Basic Questions of Mental Hygiene - The Basic Questions of Mental Hygiene]. Budapest: Nemzeti Tankönyvkiadó.

Cohen, J., McCabe, E. M., Michelli, N. M., \& Pickeral, T. (2009). School climate: Research, policy, teacher education and practice. Teachers College Record, 111(1), 180-213.

Csima, M., Fináncz, J., Nyitrai, Á., \& Podráczky, J. (2018). Research on the health literacy of professionals working in early childhood education. Kontakt, 20(4), 356-362. http://dx.doi.org/10.1016/j.kontakt.2018.10.002.

Cumming, T. (2017). Early childhood educators' well-being: An updated review of the literature. Early Childhood Education Journal, 45(5), 583-593. doi:10.1007/s10643016-0818-6.

Danis, I., Farkas, M., \& Oates, J. (2011). Fejlödés a kora gyermekkorban: hogyan is gondolkod(j)unk róla? [Develpoment in the early childhood. How we shall we think about it?] In I. Balázs (Ed.), A koragyermekkori fejlödés természete - fejlödési lépések és kihivások. Biztos Kezdet kötetek II. (pp. 25-68). Budapest: Nemzeti Család- és Szociálpolitikai Intézet.

Európai Lakossági Egészségfelmérés 2014/2015-ös kérdőive [European Health Interview Survey 2014/2015 Questionnaire]. Retrieved from https://www.ksh.hu/elef/pdfs/elef2014_kerdoiv.pdf.

Fekete, S. (1991). Segitö foglalkozások kockázatai. Helfer szindróma és burnout jelenség [The Risks of Helping Professions. Helfer Syndrome and Burnout]. Psychiátria Hungarica, 6(1),17-29.

Halász, G. (1980). Az iskolai szervezet elemzése [Analysis of School Organization.]. Budapest: MTA Pedagógiai Kutatócsoport. 
Hall-Kenyon, K. M., Bullough, R. V., MacKay, K. L., \& Marshall, E. E. (2014). Preschool teacher well-being: A review of the literature. Early Childhood Education Journal 42, 153-162. doi:10.1007/s10643-013-0595-4.

Halpin, A. W., \& Croft, D. B. (1963). The organisational climate of schools. Chicago: Midwest Administration Centre, University of Chicago

Health Survey. (2017). The mental health and wellbeing of education professionals in the UK. Retrieved from https://www.educationsupportpartnership.org.uk/sites/default/files/education_staff_healt h_survey_2017.pdf.

Heckman, J. J., Moon, S. H., Pinto, R., Savelyev, P. A., \& Yavitz, A. (2010). The rate of return of the high/scope perry preschool program. Journal of Public Economics, 94(1-2), 114-128.

Horn, J. E., Taris, T. W., Schaufeli, W. B. \& Schreurs, P. G. (2004). The structure of occupational well being: A study among Dutch teachers. Journal of Occupational and Organizational Psychology 77, 365-375. doi:10.1348/0963179041752718.

International Standard Classification of Education. (2012). ISCED 2011. Montreal, Quebec: UNESCO Institute for Statistics. Retrieved from http://uis.unesco.org/sites/default/files/documents/international-standard-classificationof-education-isced-2011-en.pdf.

Kopp, M., \& Kovács, M. (Eds.). (2006). A magyar népesség életminösége az ezredfordulón [The Hungarian Population's Quality of Life at the Millennium]. Budapest: Semmelweis Kiadó.

Kopp, M., \& Skrabski, Á. (2006). Magyar lelkiállapot az ezredforduló után [Hungarian State of Mind after the Millennium]. Retrieved from http://www.tavlatok.hu/86/86kopp_skrabski.pdf.

Kusma, B., Groneberg, D. A., Nienhaus, A., \& Mache, S. (2012). Determinants of day care teachers' job satisfaction. Central European Journal of Public Health, 20(3), 191198. doi:10.21101/cejph.a3700.

Maslach, C., \& Jackson, S. E. (1981). The measurement of experienced burnout. Journal of Occupational Behavior 2, 99-113. https://doi.org/10.1002/job.4030020205.

Milotay, N. (2004). Az Európai Unió pedagógusképzési és továbbképzési politikája [European Union Teacher Training and Further Training Policy]. Educatio, 13(3), 431440.

OECD (2012). Investing in high-quality early childhood education and care (ECEC).

OECD (2017). Starting strong 2017: Key OECD indicators on early childhood education and care. Paris: OECD Publishing.

Pete, J. (2016). Helyzetjelentés a pedagógus életpályamodellröl - alul-, felül- és oldalnézetben [Report on Teacher Career Path Viewed from Below, Above and the Sides]. Autonómia és Felelösség, 2(2-3), 89-97. 
Royer, N., \& Moreau, C. (2016). A survey of Canadian early childhood educators' psychological wellbeing at work. Early Childhood Education Journal, 44(2), 135-146. doi:10.1007/s10643-015-0696-3.

Saunders, S. (2018). The organisational climate of preschools and associated characteristics. A study of a group of preschools in England (Unpublished doctoral dissertation). UWIC Cardiff Metropolitan University.

Schweinhart, L. J., Barnes, H., \& Weikart, D. P. (1993): Significant benefits: the highscope perry preschool study through age 27. Ypsilanti, MI: High-Scope Press.

Shpancer, N., Dunlap, B., Melick, K.M., Coxe, K. Kuntzman, D., Sayre, P. S., Toto, C., \& Spivey, A. T. (2008). Educators or babysitters? Daycare caregivers reflect on their profession, Child Care in Practice, 14(4), 401-412, doi: 10.1080/13575270802267994.

Skrabski, Á., Kopp, M., Rózsa, S., \& Réthelyi, J. (2006). A koherencia, az élet értelme, mint az életminöség fontos dimenziója [Coherence, Meaning of Life, as an Important Dimension of Quality of Life]. In M. Kopp \& E. Kovács (Eds.), A magyar népesség életminősége az ezredfordulón (pp.146-155). Budapest: Semmelweis Kiadó.

Tagiuri, R., \& Litwin, G. (Eds.). (1968). Organizational climate: Explorations of a concept. Boston: Harvard Business School.

Tímár, É. (2006). Tantestületi légkörvizsgálat [The Examination of Teaching Staff Atmosphere]. Iskolakultúra $17(3)$. Retrieved from http://real.mtak.hu/57702/1/EPA00011_iskolakultura_2006_03_011-023.pdf.

Yildirim, K. (2014). Main factors of teachers' professional well-being. Educational Research and Reviews 9(6) 153-163. doi:10.5897/ERR2013.1691.

Vitályos, G. Á., Dancs, G., Bärnkopfné, Zs. K., Venyingi, B., \& Darvay, S. (2018). Egyetemi hallgatónők vérnyomásának, tápláltsági állapotának és életvitelének összefüggései [Correlations of Female University Students' Blood Pressure, Nutritional Condition and Lifestyle]. Anthropologiai Közlemények, 59, 31-45. doi:10.20330/AnthropKozl.2018.59.31.

Whitaker R. C., Becker B. D., Herman A. N., \& Gooze R. A. (2013). The physical and mental health of head start staff: The Pennsylvania head start staff wellness survey, 2012. Preventing Chronic Diseases, 10, 130171. http://dx.doi.org/10.5888/pcd10.130171.

Williamson, L., Davis, E., Priest, N., \& Harrison, L. (2011). Australian family day care educators: A snapshot of their qualifications, training and perceived support. Australian Journal of Early Childhood, 36(4), 63-68. 